\title{
Meiofauna and harpacticoid copepods in different habitats of a Mediterranean seagrass meadow
}

\author{
THIBAUD MASCART ${ }^{1,2}$, GILLES LEPOINT ${ }^{2}$ AND MARLEEN DE TROCH ${ }^{1}$ \\ ${ }^{1}$ Marine Biology, Ghent University, Krijgslaan 281-S8, B-900o Ghent, Belgium, ${ }^{2}$ Laboratory of Oceanology, University of Liège, Allée \\ du 6 août B6, B-40oo Liège, Belgium
}

\begin{abstract}
This study investigated whether associated meiobenthic communities, especially harpacticoid copepods, differed amongst habitats. Five pre-defined habitats within and next to the Posidonia oceanica seagrass meadow were sampled: living seagrass canopy leaves (LL), small (SMF) and large (LMF) macrophytodetritus fragment accumulations and sand, bare (BS) and covered (CS). The highest meiofauna abundances were recorded in the BS for the core sampled habitats (BS, CS, SMF and $L M F$ ) and in the LMF for seagrass material habitats (SMF, LMF and LL). Harpacticoid copepods were the most abundant taxon in all habitats. The assemblage composition at copepod family level showed two distinct habitats clusters: a leaf (LMF and LL) and a sediment cluster (BS, CS and SMF). Subsequently, stable isotope analyses were conducted to analyse the relationship between copepods and their potential food sources in seagrass material habitats. Based on $\delta^{13} C$ isotopic analyses and SIAR mixing model, harpacticoid copepods relied for $70 \%$ on epiphytes and for $30 \%$ on P. oceanica leaf material in the LMF and LL habitats.
\end{abstract}

Keywords: meiofauna, harpacticoid copepods, seagrass, detritus, Posidonia oceanica, stable isotopes

Submitted 18 January 2013; accepted 15 February 2013; first published online 3 April 2013

\section{INTRDDUCTION}

The endemic Posidonia oceanica (L.) Delile, the dominant seagrass in the Mediterranean Sea, is a long-living organism displaying considerable autumnal leaf fall (Pergent et al., 1997). The macrophytodetritus is scattered by currents and waves, and accumulates in situ or is exported to adjacent habitats where it degrades and often becomes predominant (Mateo et al., 2003; Cardona et al., 2007). Accumulation of macrophytodetritus on sand patches adjacent to the seagrass meadow can be substantial, i.e. several hundred cubic metres, especially in relative enclosed systems (Cebrian \& Duarte, 2001). These patches are ephemeral environments which remain for a few days to several months depending on the degradation rate and hydrodynamics of the area (Mateo \& Romero, 1997). The accumulated materials are heterogeneous, mainly composed of phytodetritus (variable in size and degradation status), but also of living seagrass shoots and macroalgae. Macrophytodetritus nutritional quality is low due to its high lignocellulose content and its nutritional depletion by N-resorption and recycling before abscission (Lepoint et al., 2002). Nevertheless, macrophytodetritus is typically colonized by epiphytic organisms, i.e. all organisms associated with phytal habitats (leaves) such as e.g. heterotrophic microbial communities (bacteria and fungi), autotrophes (e.g. epiphytic diatoms), protists,

Corresponding author:

T. Mascart

Email: thibaud.mascart@ugent.be meiofauna and macrofauna (Danovaro, 1996; Gallmetzer et al., 2005). The latter two refer to metazoans passing through a $1 \mathrm{~mm}$ sieve retained on a $38 \mu \mathrm{m}$ screen and retained on a $1 \mathrm{~mm}$ sieve, respectively. A possible reason for the high colonization is that macrophytodetritus create the conditions for the development of a high structural diversity of associated communities. This condition is generated on one hand by physical fragmentation, due to hydrodynamism or biological fragmentation through foraging behaviour. On the other hand by the higher nutritional quality of the epiphytic organisms compared to macrophytodetritus and also the accessibility of those epiphytic organisms that serve as food sources (hereafter referred to as epiphytes) for associated consumers. These consumers are likely to be crucial for the degradation and transport of organic matter to higher trophic levels. For example, macrofauna (juvenile fish prey) is known to ingest detritus with their associated epiphytes and microbial communities (Romero et al., 1992; Vizzini et al., 2002; Mateo et al., 2003; Lepoint et al., 2006; Sturaro et al., 2010). As such, seagrass ecosystems hold a significant fraction of autotrophic biomass (Duarte et al., 2005) that is passed indirectly to higher trophic levels. It can thus be assumed that these ecosystems are macrophytodetritus based (Romero et al., 1992; Mateo \& Romero, 1997; Pergent et al., 1997).

Little is known on the exact role of meiofauna in the macrophytodetrital accumulations. Posidonia oceanica beds are hotspots for meiofaunal production ranging between 7.5 and $13.2 \mathrm{~g} \mathrm{C} \mathrm{m}^{-2} \mathrm{yr}^{-1}$ (Danovaro et al., 2002). These values are comparable to the ones reported for seagrass systems in general, but are higher than the meiofaunal production in the Atlantic, the North Sea or the Baltic Sea. Meiofauna 
organisms occur in high densities, have a high turnover rate and most probably spend their entire lifecycle on or around the same substrate (Giere, 2009). They are known to feed on a wide variety of food sources, including epiphytic biofilm (Hicks \& Coull, 1983; Caramujo et al., 2008; De Troch et al., 2008, 2009). Meiofaunal studies mainly focus on patterns of occurrence in sediment habitats (Danovaro et al. 2000; Mirto et al., 2010) or in the epiphytal canopy environment (Hall \& Bell, 1993). Studies combining both habitats are very limited (Bell et al., 1984; De Troch et al., 2001) and hardly focus on the third non-negligible habitat in this system, namely the macrophytodetritus accumulation on sand patches (Dimech et al., 2006). The present study aimed to characterize the meiofaunal community and diversity in different habitat types, namely seagrass canopy, adjacent sand and macrophytodetritus accumulations. In addition to the structural diversity of meiofauna, a more functional approach concentrating on harpacticoid copepods is included. Hence, natural stable isotope signatures $\left(\delta^{13} \mathrm{C}\right)$ are used to trace food sources in consumers (Fry et al., 1987; Lepoint et al., 2000; Vizzini et al., 2002). Potential food sources and harpacticoid copepods from the different habitats were analysed to infer their diet and to study what are the main food sources for harpacticoid copepods at the basis of the food web in the seagrass ecosystem. As the trophic position of copepods in the sediments has been already documented (Carlier et al., 2007; Wyckmans et al., 2007), the present research will clarify which part of the seagrass ecosystem is consumed by harpacticoid copepods, i.e. the macrophytodetrital matter, the epiphytic biofilm or the living leaves.

\section{MATERIALS AND METHDDS}

\section{Sampling site and strategy}

Samples were collected in the Revellata Bay (Gulf of Calvi, Corsica, north-west Mediterranean) at the Punta Oscelluccia site $\left(42^{\circ} 35^{\prime} \mathrm{N} 8^{\circ} 43^{\prime} \mathrm{E}\right)$ (Figure 1 ). The sampling site was located close to a sandy patch and in a Posidonia oceanica meadow facing the Oscelluccia peninsula (Punta Oscelluccia).

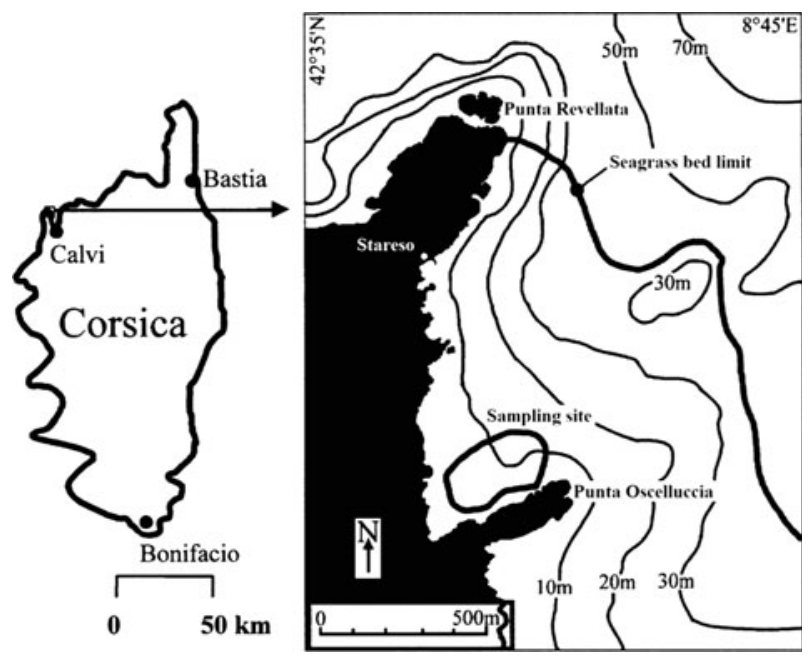

Fig. 1. Location of the Revellata Bay within the sampling site and the Posidonia oceanica meadow isobaths with lower depth distribution limit. Adapted from Gobert et al. (2003)
At the study site, $P$. oceanica seagrass meadows cover about $50 \%$ of the total bay surface down to a depth of $38 \mathrm{~m}$ (Bay, 1984 ) and are ranked among the most productive $P$. oceanica beds in the north-west Mediterranean (Pergent-Martini et al., 1994). Samples were taken in August 2009, which correlates with the start of the autumnal leaf fall cycle. Sampling was carried out at a depth of $10 \mathrm{~m}$ by SCUBA divers during day time. The salinity, around 38 , and the water temperature, around $26^{\circ} \mathrm{C}$, remained stable during the entire sampling campaign.

Five potential habitats for meiofauna were collected in triplicate. The meadow leaves stratum, living leaves of the $P$. oceanica canopy (abbreviation: LL) represented a first potential habitat. Two different types of $P$. oceanica macrophytodetritus accumulated on adjacent sand patches were included as other habitat options: large macrophytodetritus fragments (abbreviation: LMF) comprising leaf lengths from 0 to $30 \mathrm{~cm}$ of $P$. oceanica and small macrophytodetritus fragments (abbreviation: SMF) comprising leaf length restricted from o to $3 \mathrm{~cm}$ of $P$. oceanica. Finally, two sand habitats of adjacent sand patches were sampled: bare sand (abbreviation: BS) and sand covered by macrophytodetrital material of $P$. oceanica (abbreviation: CS).

Living $P$. oceanica shoots representing the living leaves stratum (LL) were cut off at the sediment-water interface and put in 21 plastic jars. The large macrophytodetritus fragments (LMF) and small macrophytodetritus fragments (SMF) were sampled using a $25 \mathrm{~cm}$ diameter tube randomly placed on the macrophytodetritus patch. All macrophytodetritus present inside the tube were scooped off from the seafloor by hand and collected in 21 plastic jars. For the sand samples (BS and CS), $20 \mathrm{~cm}^{2}$ surface area and $5 \mathrm{~cm}$ deep cores of bare sand were collected. In order to clear the covered sand sample present underneath the macrophytodetrital material, the latter was very carefully moved aside to avoid fine sediment being brought in suspension and to get access to the bare sand. All jars were closed under water to ensure no loss of material or contamination of the samples. Standardization over all samples was not possible due to the different sampling techniques. Therefore two standardizations were made: one to compare all cored samples (BS, CS, SMF and LMF) per unit of surface $\left(10 \mathrm{~cm}^{-2}\right)$ and one to compare all seagrass material (SMF, LMF, LL) per unit of dry weight $\left(\mathrm{g}^{-1} \mathrm{DW}\right)$.

\section{Community characterization}

In order to extract the attached meiofauna, a $8 \%$ $\mathrm{MgCl}_{2}$-solution was added to stun the organisms (Hulings \& Gray, 1971). Samples were afterwards rinsed twice over a $1 \mathrm{~mm}$ mesh sieve to exclude macrofauna and on a $38 \mu \mathrm{m}$ mesh sieve to retain the meiofauna, prior to preservation with a $4 \%$ formaldehyde seawater solution. In the laboratory, the $38 \mu \mathrm{m}-1 \mathrm{~mm}$ fraction of each replicate was centrifuged three times with Ludox HS40 (specific density of $1.18 \mathrm{~g} / \mathrm{dm}^{3}$ ). Meiofauna was stained with rose Bengal before being sorted and enumerated at a higher taxon level based on Higgins \& Thiel (1988) using a Wild M5 binocular. One hundred harpacticoid copepods were randomly picked and stored in $75 \%$ ethanol. Copepods were mounted on glycerine slides for further identification to copepod family level using the identification keys and reference books by Boxshall \& Hasley (2004) and Lang (1948, 1965). 


\section{Environmental data}

The samples for the community characterization were also used to assess the total organic carbon content (TOC). Subsamples were weighed after being dried at $60^{\circ} \mathrm{C}$ for $72 \mathrm{~h}$. TOC was measured after acidification with $\mathrm{HCl}$ and pulverization for 30 minutes of the dried material. TOC analyses were carried out with a ThermoFinnigan Flash1112 elemental analyser using the method of Niewenhuize et al. (1994).

\section{Trophic biomarkers}

For stable isotope analysis separate qualitative samples were taken from the seagrass material habitats. The two macrophytodetritus habitats (SMF and LMF) were sampled using $30 \mathrm{l}$ bags where the material was scooped in by hand. The living leaves habitat was sampled by cutting five shoots at the sediment interface. All samples were afterwards kept in aquaria in order to collect harpacticoid copepods using positive phototaxis attraction and a pipette. The extracted copepods were rinsed and placed overnight in filtered seawater to empty their gut content. Two potential food sources including leaves (living or as macrophytodetritus) without and with associated epiphytes were collected according to the technique used by Dauby \& Poulicek (1995). The leaves without epiphytes, the epiphytes and the copepod samples (6o ind. sample ${ }^{-1}$ in order to have a sufficient amount of carbon for reliable measurements) were stored directly after collection in liquid nitrogen at $-80^{\circ} \mathrm{C}$. All the samples were dried afterwards for $24 \mathrm{~h}$ at $60^{\circ} \mathrm{C}$ and loaded into tin capsules for isotopic measurements with a C-N-S elemental analyser (Carlo Erba, Italy) coupled to a mass spectrometer (VG Optima, Micromass, UK). Prior to the encapsulation all seagrass material potential food sources were ground, except for harpacticoid copepods. The isotopic data were expressed as $\delta$ value (\%o) relative to the VPDB (Vienna Peedee Belemnite) carbon standard. Reference material used to calibrate was IAEA (International Atomic Energy Agency) $\mathrm{CH}-6\left(\delta^{13} \mathrm{C}=-10.4 \pm 0.2 \%\right)$. The standard deviation of repeated $\delta^{13} \mathrm{C}$ measurements of the internal standard was $\pm 0.2 \%$.

Contribution of potential food sources to the carbon pool of harpacticoid copepods was estimated by a SIAR mixing model developed in R (Parnell et al., 2010). The model was run for 500,000 iterations and the first 50,000 iterations were discarded. Isotopic ratios of copepods and food sources were compared considering a trophic enrichment of $0.2 \pm$ $0.6 \%$ for $\delta^{13} \mathrm{C}$ (adapted from Vander Zanden (2001)). In this study only the mode and lowest and highest $0.95 \%$ confidence interval (CI) were detailed. The value used in the model was the overall mean of epiphytes from the two other habitats $(-20.0 \pm 1.0 \%$ o $)$, due to the lack of data on epiphytes from small macrophytodetritus fragments. To reduce the number of food sources and to avoid bias, the model was run with two sources (epiphytes and leaves without attached epiphytes), except for the small macrophytodetritus fragments where no separation of epiphytes was possible, leaves with epiphytes were used. The living leaves and macrophytodetritus with associated epiphytes were not considered in the mixing models since this source was a combination of two other potential food sources and therefore biasing the mixing model outcome.

\section{Data analysis}

Diversity indices were calculated using $S$, the number of meiofauna taxa or copepod families, $N_{\text {inf, }}$ the dominance index, the reciprocal of the proportional abundance of the most common taxon or family (reciprocal of the Berger-Parker index), $J^{\prime}$, the Pielou evenness index and $H^{\prime}$, the ShannonWiener diversity index based on the natural logarithm (ln). A resemblance matrix based on Bray-Curtis similarities was constructed from the log transformed abundances for meiofaunal taxa and harpacticoid copepod families. A cluster analysis based on the Bray-Curtis similarity matrix was performed to explore community structure similarities among the different habitats using the group average linkage method. Prior to the cluster analysis an analysis of similarity (ANOSIM) was carried out to test whether the defined communities (based on habitats) were significantly different. A similarity percentages (SIMPER) analysis based on a BrayCurtis similarity matrix of the harpacticoid copepod composition was done to reveal which families characterize and discriminate each habitat. All the above mentioned analyses were performed with the Primer 6.0 software (Clarke \& Gorley, 2006). Differences in composition among all habitats were tested by means of a one-way analysis of variance (ANOVA) done on relative data. A posteriori comparisons were carried out with the Tukey test using 95\% confidence limits. Significant differences among two habitats were tested by means of a $t$-test. The ANOVAs, Tukey tests, $t$-tests and graphs were made using GraphPad 5.04 for Windows (GraphPad Software, La Jolla, California BSA).

\section{RESULTS}

\section{Meiofauna communities}

For meiofauna abundances the standardization against surface area yielded a decreasing trend: $217.5 \pm 92.8$ ind. $10 \mathrm{~cm}^{-2}$ (BS), $\quad 146.2 \pm 63.6$ ind. $10 \mathrm{~cm}^{-2}$ (LMF), $\quad 72.1 \pm 26.7$ ind. $10 \mathrm{~cm}^{-2}$ (CS) and $57.8 \pm 20.2$ ind. $10 \mathrm{~cm}^{-2}$ (SMF) (Figure 2A). In terms of meiofaunal densities, all four cored habitats were significantly different (one-way ANOVA, $F(3,8)=4.75, \quad P=0.0035)$. The Tukey test comparison revealed that only BS and SMF were significantly different from each other (Tukey, $P<0.05$ ). Standardization against dry weight generated the following decreasing trend: $39.4 \pm$ 4.1 ind.g ${ }^{-1} \mathrm{DW}$ (LMF), $14.9 \pm 3.0$ ind.g ${ }^{-1}$ DW (SMF) and $13.9 \pm 2.0$ ind.g ${ }^{-1}$ DW (LL) (Figure $2 \mathrm{~B}$ ). Regarding meiofaunal densities, all three seagrass material habitats were significantly different (one-way ANOVA, $F(2,6)=54.42, P<$ $0.0001)$. The Tukey test comparison revealed that only SMF and LL were not significantly different from each other (Tukey, $P>0.05$ ).

In relation to relative composition, $88 \%$ of all organisms belonged to three taxa: copepods, nematodes and polychaetes. Copepods represented the highest average relative abundance of $49.4 \pm 3.4 \%$ with a maximum of $54.1 \pm 4.8 \%$ in LFM. Nematodes accounted on average for $23.3 \pm 6.8 \%$ with a maximal density of $32.3 \pm 6.4 \%$ in SFM. Polychaetes accounted on average for $15.0 \pm 5.1 \%$ with a maximum of $24.1 \pm 2.2 \%$ in the LL. The remaining $12 \%$ consisted of, in order of decreasing abundance: juvenile Amphipoda, nauplii, Ostracoda, Tanaidacea, Isopoda, Halacarida, Turbellaria, 

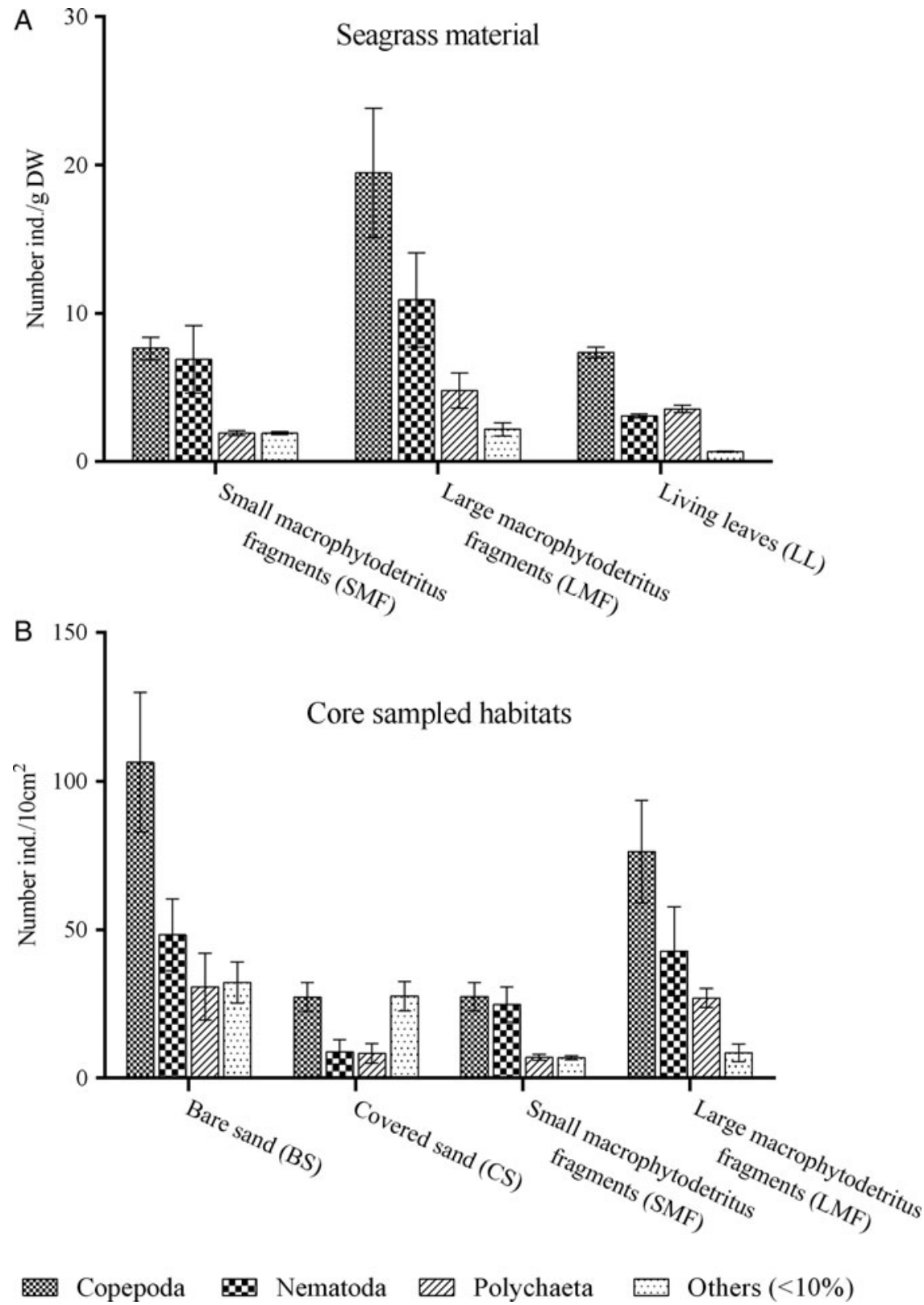

Fig. 2. Mean meiofauna densities per habitat type. (A) Mean densities in $\mathrm{gDW}^{-1}$; (B) mean densities in $10 \mathrm{~cm}^{-2}$ surface area. Error bars represent the standard deviation $(N=3)$.

Leptostraca, Oligochaeta, Tardigrada, Decapoda, Chaetognatha, Cnidaria, Pycnogonida, Cumacea and Paguroidea.

The meiofaunal community did not show any significant difference among the habitats in terms of assemblage structure (ANOSIM, $R=0.37, P=0.001$ ), with an overall similarity of $84 \%$ (SIMPER). The diversity indices showed no significant differences among all five habitats ( $t$-test, $p$-values $>0.05$ ) (Table 1).

\section{Copepoda family composition}

For harpacticoid copepod abundances, standardization against surface area yielded the same decreasing trend as for meiofauna: $10.6 \pm 4.1$ ind. $10 \mathrm{~cm}^{-2}$ (BS), $7.6 \pm 3.0$ ind. $10 \mathrm{~cm}^{-2}$ (LMF), $2.7 \pm 0.8$ ind. $10 \mathrm{~cm}^{-2}$ (CS) and $2.7 \pm$ 0.8 ind. $10 \mathrm{~cm}^{-2}$ (SMF) (Figure $2 \mathrm{~A}$ ). In terms of copepod densities, all four cored habitats were significantly different (one-way ANOVA, $F(3,8)=6.7, P=0.0141$ ). The Tukey test comparison revealed that only BS vs CS and BS vs SMF were significantly different from each other (Tukey, $P<$ 0.05). Standardization against dry weight generated the following decreasing trend: $19.5 \pm 1.3$ ind.g ${ }^{-1}$ DW (LMF), $7.0 \pm 0.70$ ind.g $^{-1}$ DW (LL) and $6.2 \pm 1.9$ ind.g ${ }^{-1}$ DW (SMF) (Figure $2 \mathrm{~B}$ ). In terms of copepod densities, all three seagrass material habitats were significantly different (one-way ANOVA, $F(2,6)=87.95, P<0.0001$ ). As observed for meiofauna, the Tukey test revealed that only SMF and LL were not significantly different (Tukey, $P>0.05$ ).

In total, four copepod orders and 16 harpacticoid families were found in 1500 identified copepod specimens. The majority of the copepods $(90.6 \pm 3.0 \%)$ belonged to the order Harpacticoida. The remaining copepods were 
copepodites $(2.9 \pm 2.8 \%)$, representatives of the Cyclopoida order $(6.1 \pm 2.8 \%)$ or belonged to the orders Calanoida and Misophrioida ( $0.4 \pm 0.3 \%$ together). Since only a minority (few \%) of the collected copepods did not belong to the Harpacticoida order, further analysis focused only on the latter. The harpacticoid families found, in decreasing order according to their overall relative abundance, were, Tisbidae, Thalestridae, Miraciidae, Laophontidae, Ameiridae, Longipediidae, Ectinosomatidae, Tetragonicepsidae, Harpacticidae, Porcellidiidae Ancorabolidae, Peltidiidae, Canuellidae, Tegastidae, Cletodidae and Cylindropsyllidae.

The harpacticoid copepods showed a significant difference among the habitats in terms of assemblage structure (ANOSIM, $R=0.92, P=0.001$ ), with an overall dissimilarity of $53 \%$ (SIMPER). ANOSIM habitat type pairwise comparisons test separated well all groups $(R>0.75)$ except for BS\&CS and LMF\&LL showing overlap but still yielding a difference of $R=0.70$ and $R=0.63$, respectively. Cluster analysis (Figure 3) revealed two major clusters: cluster 1 with an overall similarity of $62.6 \%$ and cluster 2 with an overall similarity of $52.9 \%$. In the first cluster (cluster 1 ) a clear distinction was found among two habitats: the large macrophytodetritus fragments (cluster $1 \mathrm{~A}, 71.7 \%$ similarity) and the living leaves (cluster $1 \mathrm{~B}, 68.7 \%$ similarity). The second cluster (cluster 2) consisted of: two replicates of covered sand (cluster $2 \mathrm{~A}, 81.0 \%$ similarity) and a cluster $(2 \mathrm{~B}, 62.6 \%$ similarity) of small macrophytodetritus fragments, bare sand and a single replicate of covered sand.

The two main clusters were significantly different (ANOSIM, $R=90, P=0.001$ ), showing an average dissimilarity of $61.7 \%$ (SIMPER). Cluster 1 had an overall average similarity percentage of $67.4 \%$ and four harpacticoid families were abundant with a cumulative contribution to the similarity of $86.8 \%$. According to SIMPER analysis, the families primarily responsible for the similarity were, in decreasing order: Thalestridae (48.2\%), Laophontidae (20.4\%), Miraciidae (8.5\%) and Tisbidae (8.7\%). Cluster 2 had an average overall similarity percentage of $63.3 \%$ and was mainly characterised by three families with a cumulative contribution of $89.4 \%$ (SIMPER). A different decreasing contribution order was seen in comparison to cluster 1: Tisbidae (57.1\%), Miraciidae (21.9\%) and Thalestridae (10.4\%) (Figure 4).

No significant differences were found in number of families $(t$-test, $t(13)=1.4, P=0.199)$ between cluster $1(S=9.5 \pm$ $1.5)$ and cluster $2(S=8.0 \pm 2.4)$. In contrast to the significant difference among all habitats (one-way ANOVA, $F(4,10)=12.0, P=0.0008)$, there was no significant difference among both clusters in terms of dominance index and Shannon-Wiener index ( $t$-test, $t(19)=1.0, P=0.333$ and $t(13)=2.1, P=0.056$, respectively). The Pielou's evenness index showed a significant difference between the two clusters $(t$-test, $t(13)=2.6, P=0.023)($ Table 1$)$.

\section{Environmental data}

Total organic carbon values showed significant differences among the habitats (one-way ANOVA, $F(2,3)=179.7, P=$ 0.0008) except for SMF and LMF comparison (Tukey, $P>$ 0.05). Following TOC content were found in decreasing order: LL (31.0 $\pm 0.5 \%)$, LFM (20.6 $\pm 0.3 \%)$, SFM (19.7 \pm $1.0 \%)$ and the sand habitats $(<0.1 \%)$. 


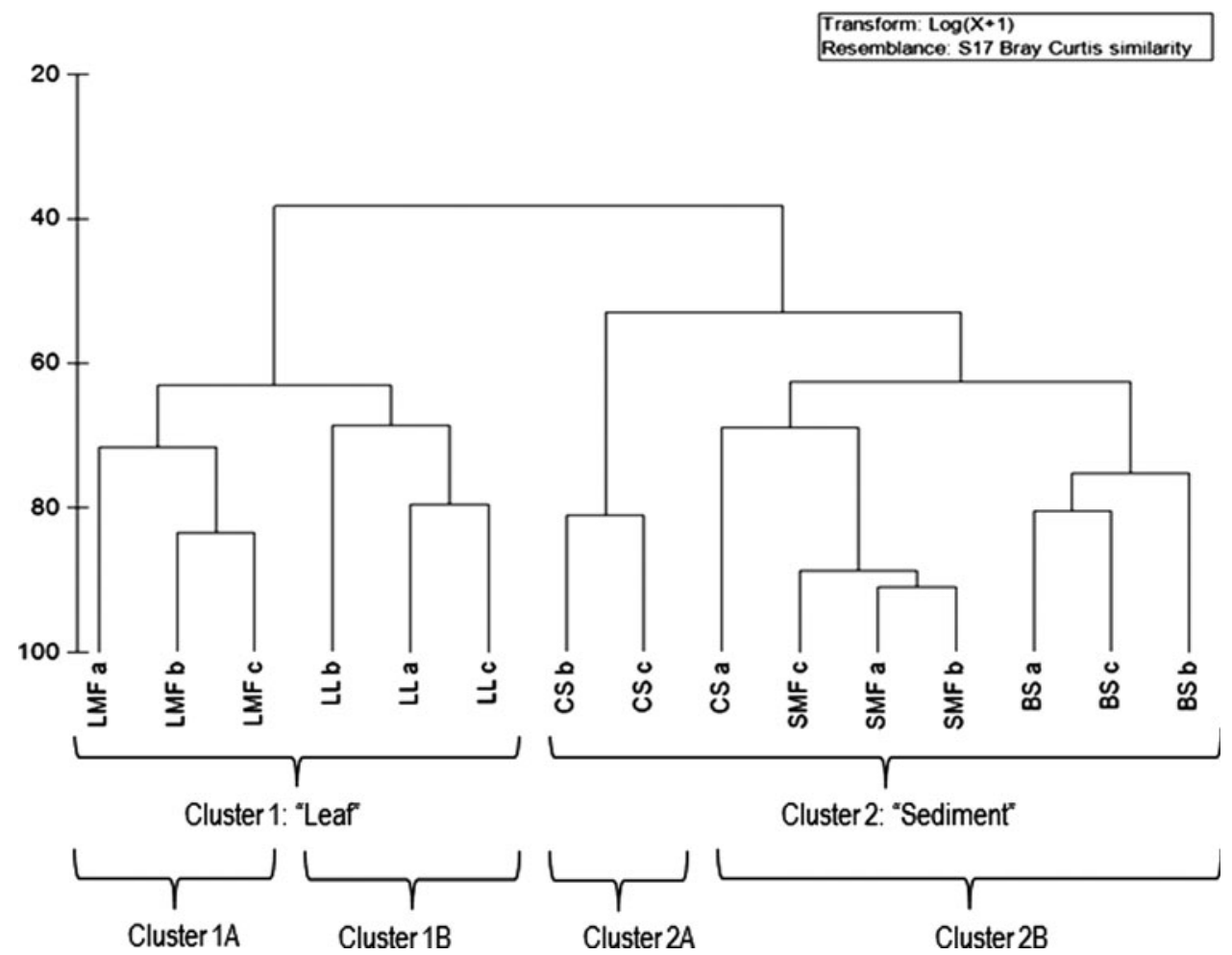

Fig. 3. Cluster analysis of relative harpacticoid copepod densities. LL, living leaves; LMF, large macrophytodetritus fragments; SMF, small macrophytodetritus fragments; CS, covered sediments; BS, bare sand. similarity coefficient in $\%$ on $y$-axis and a, b, c refer to the replicates.

\section{Trophic interactions by means of stable isotopes}

Harpacticoid copepods from the different seagrass material habitats showed slightly different, but analogous $\delta^{13} \mathrm{C}$ values: $-16.6 \pm 1.1 \%$ (LL), $-18.5 \pm 1.3 \%$ (LMF) and $-16.8 \pm 1.1 \%$ (SMF) (Figure 5). Leaves with epiphytes were the most enriched ${ }^{13} \mathrm{C}$ sources: $\delta^{13} \mathrm{C}=-9.1 \pm 1.5 \%$ (LL) and $\delta^{13} \mathrm{C}=-14.5 \pm 1.5 \%$ (LMF), however collection of epiphytes from SMF could not be achieved due to the high fragmentation and fragility of the macrophytodetrital material. Therefore only SMF with associated epiphytes could be analysed $\left(\delta^{13} \mathrm{C}=-13.7 \pm 1.1 \% 0\right)$, which ranged within the values of LMF without epiphytes. The epiphytes present on the LL and on the LMF material (Figure 5) were by far the most depleted $\left(\delta^{13} \mathrm{C}=-19.5 \pm 2.2 \% 0\right.$ and $-20.0 \pm 1.0 \%$, respectively) in the three seagrass material habitats. The combination of living leaves and macrophytodetritus with their attached epiphytes ranged between the values

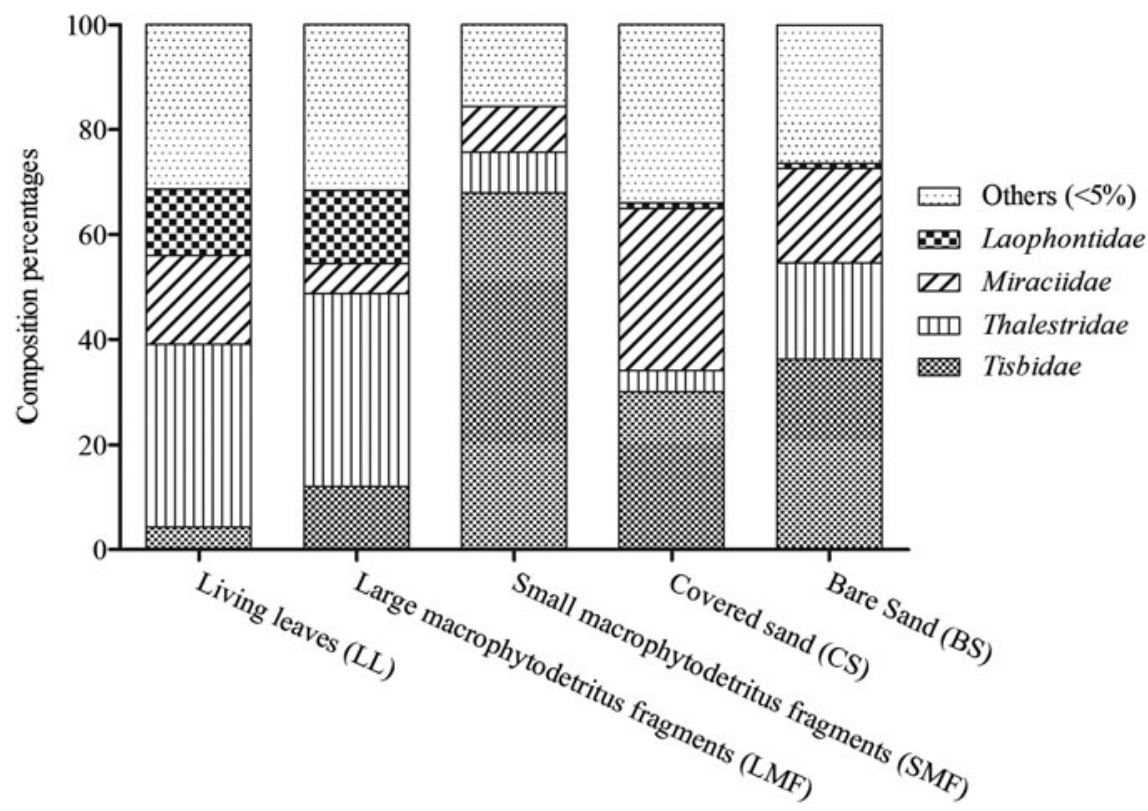

Fig. 4. Mean relative composition (\%) of the harpacticoid copepod families. Families shown represent a total contribution of more than $5 \%$ over all samples. 


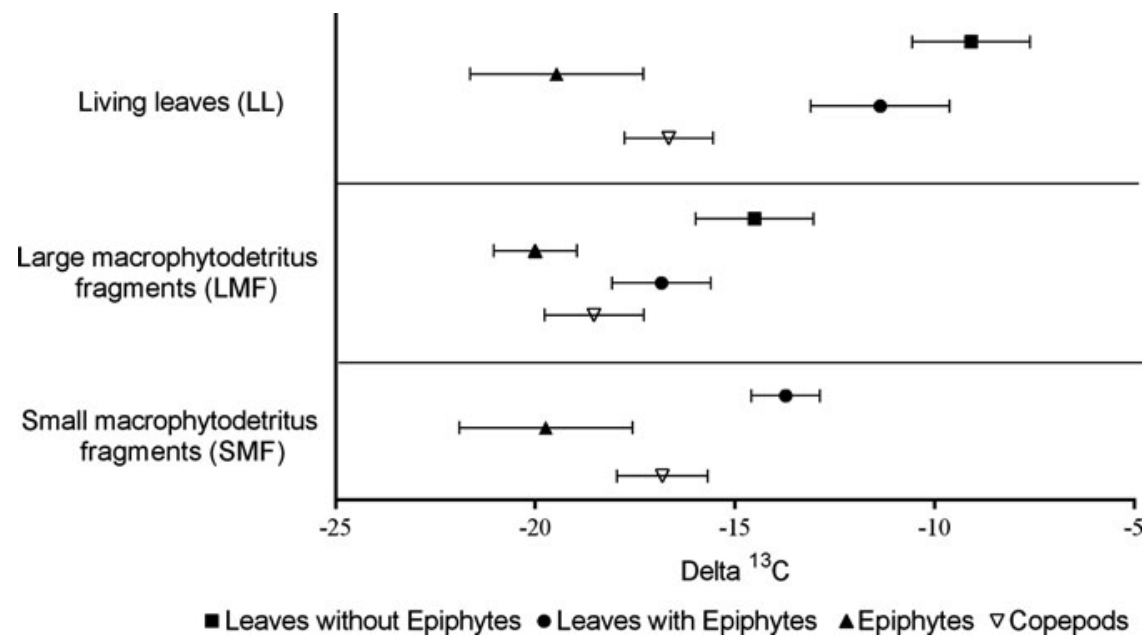

Fig. 5. $\delta^{13} \mathrm{C}$ values (\%) of plant material as potential food sources and copepods (mean $\pm \mathrm{SD}, N=3$ ). The full symbols are potential sources: leaves (living or macrophytodetritus) without epiphytes (squares), the removed epiphytes (triangles) and the leaves (living or macrophytodetritus) with their epiphytes (rounds). The open symbols are the harpacticoid copepods, primary consumers (reversed triangles).

of the two latter separately with $\delta^{13} \mathrm{C}=-11.4 \pm 1.8 \%$ and $-16.9 \pm 1.2 \%$ for the LL and the LMF, respectively (Figure 5 ).

Mixing model computation showed higher contribution of epiphytes than leaf material as carbon source for copepods in LL and LMF. For the LL habitat, epiphytes 0.95 confidence interval (CI) ranged from $42 \%$ to $97 \%$ (mode $70 \%$ ) and LL without epiphytes 0.95 CI was $2-57 \%$ (mode $30 \%$ ). For LMF, epiphytes 0.95 CI ranged from $37 \%$ to $99 \%$ (mode $72 \%$ ) and for LMF without epiphytes 0.95 CI was $0-63 \%$ (mode 28\%). For SMF habitat, epiphytes 0.95 CI ranged from $23 \%$ to $81 \%$ (mode $51 \%$ ) and SMF with epiphytes 0.95 CI ranged from $18 \%$ to $76 \%$ (mode $49 \%$ ) (Figure 6 ).

\section{DISCUSSIDN}

In the present study, it was remarkable to see that harpacticoid copepods numerically dominated the meiofauna samples in all habitats. Half of the meiofaunal organisms were harpacticoid copepods and only a quarter were nematodes. This is in contrast with most studies on meiofauna in seagrass meadows sediments (e.g. Fonseca et al., 2011; Losi et al., 2012) where nematodes dominate numerically. Nevertheless, dominance of copepods is often documented for seagrass meadow canopy leaves (Hall \& Bell, 1993; De Troch et al., 2001; Hooper \& Davenport, 2006).

The analysis of meiofauna at taxon level did not show any significant differences among the different habitats either in terms of assemblage composition or diversity. Indeed, the five habitats presented a high similarity, i.e. more than $84 \%$ (SIMPER). The LMF had the highest meiofaunal abundance from the seagrass material habitats which could indicate that the potential food quality/quantity or protection from predation was the highest in these habitats. A potential increase in complexity can be a reason for this, however concrete measurements (e.g. compactibility of the accumulation) to prove the possible rise in complexity were not part of this study. It could also be caused by an increase of biofilm quantity or quality as dead leaves are colonized by degrading microbes and generally lie on the sediment, exposed to sun light, in contrast to living leaves which are vertically disposed and often over-shaded.

Within the core sampled habitats, a significant difference in abundance between bare sand and covered sand was observed. This could be explained by the possible anoxia created by the layer of macrophytodetritus above the covered sand. We expect that the oxygen does not penetrate deep enough

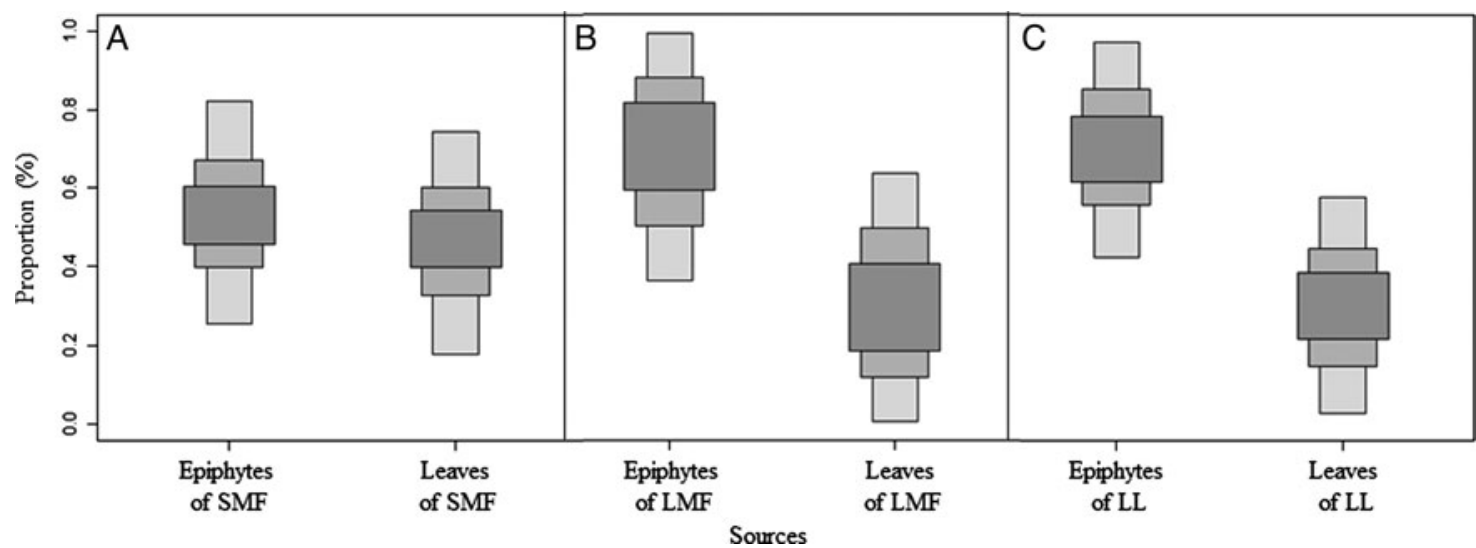

Fig. 6. SIAR boxplots show the proportional contribution (\%) of different sources to the diet of harpacticoid copepods in (A) the small macrophytodetritus fragments habitat (SMF), (B) the large macrophytodetritus fragments habitat (LMF) and (C) the living leaves habitat (LL) with 95\% (darkest grey), $75 \%$ and $25 \%$ (lightest grey) credibility intervals. 
through the macrophytodetritus to reach the sand and thus oxygen levels can become limiting. As a result, meiofauna could migrate upwards from the sand towards the macrophytodetritus. In the present study, no measurements of oxygen were available, but it could be definitely interesting to include them in future research.

In terms of harpacticoid copepod density, the same higher abundance trend for bare sand and large macrophytodetritus fragments compared to covered sand and small macrophytodetritus fragments was found, similar to the meiofauna results. We could assume that bare sand includes most of the copepods and when covered by macrophytodetritus these then migrate/emerge into large macrophytodetritus fragments. Nevertheless, in terms of harpacticoid copepod family composition, two main significantly different clusters with a similarity of approximately $38.3 \%$ were displayed. The low similarity indicates that the small macrophytodetritus fragments habitat behaves like a sediment habitat (CS and BS) and that the large macrophytodetritus fragments habitat was similar to the living leaves habitat for copepod family composition. Therefore, cluster 1 (LL and LMF) and cluster 2 (SMF, CS and BS) will further be referred to as 'leaf" and 'sediment', respectively. Thus we can hypothesize that bare sand and large macrophytodetritus fragments attract harpacticoid copepods adapted to different habitat. Harpacticoid copepods are morphologically diverse and well-adapted group occurring in numerous environments (Hicks \& Coull, 1983; Huys \& Boxshall, 1991; Boxshall \& Hasley, 2004). The phytal living leaves environment is exposed to waves and currents. Organisms living in that habitat developed attachment capabilities such as prehensile grasping legs (e.g. copepod families Thalestridae and Laophontidae) or body flattening (Porcellididae and Peltitidae). Macrophytodetritus accumulations on sandy patches are temporary, which implies that all meiofauna could be transported passively on the senescent leaves or immigrate actively from the surrounding habitat. High vagility of the phytal meiofauna was demonstrated by Bell \& Hicks (1991) and the active emergence and colonization abilities of copepods to richer or easier accessible food resources was proven by Armonies (1988) and Thistle \& Sedlacek (2004). Experiments with artificial substrates (Mirto \& Danovaro, 2004) emphasize the good swimming and colonization abilities of copepods, which partially explains the higher abundance of copepods in the large macrophytodetritus fragment. As such, the good colonization abilities of harpacticoid copepods could explain the high resemblance in terms of copepod assemblage structure between large macrophytodetritus fragments and living leaves on the one hand and between small macrophytodetritus fragments, bare sand and covered sand on the other hand. Novak (1984) stated that epiphytic cover increases from young to mature leaves. Large macrophytodetritus fragments which are senescent mature leaves exhibit a lower total organic carbon content than living leaves. Nonetheless, large macrophytodetritus fragments displays by far the highest number of individuals per gram dry weight. Therefore we can hypothesize that the content of the potential food sources does not seem to be the determining factor, but rather, the accessibility of the food source. It has been demonstrated that harpacticoid copepods occur primarily in function of resource availability (Webb, 1990), followed by hydrodynamic exposure, surface area colonizable by epiphytes (De Troch et al., 2005) and food accessibility. Well-developed and accessible epiphytic biofilms could thus enhance the species richness and density of the meiofauna (Hall \& Bell, 1993; Peachey \& Bell, 1997). This was congruent with some morphological adaptations found among the meiofaunal taxa. Only a small fraction of the phytal meiofauna (some nematodes, tardigrads and halacarids) can feed directly from the plant tissue, whereas the majority of meiofauna graze on the organic biofilm present on the leaves (e.g. Giere, 2009). Macrophytodetrital accumulations function thus as refuge from predators and provide ample food supply (Bonsdorff, 1992; Norkko et al., 2000).

Stable isotope analysis was used to identify trophic interactions and dietary relationships between the harpacticoid copepods and their potential food sources. The recorded stable isotope data of Posidonia oceanica leaves showed a range in $\delta^{13} \mathrm{C}$ values between $-13 \%$ and $-8 \%$, however most delta values varied around $-12 \%$ (Hemminga \& Mateo, 1996). These relatively high $\delta^{13} \mathrm{C}$ values compared to other potential source materials, like epiphytes $\left(\delta^{13} \mathrm{C}\right.$ value around $-20 \%$ ) make it possible to trace seagrass material in fauna diet. In our present study harpacticoid copepods were more ${ }^{13} \mathrm{C}$ depleted than the $P$. oceanica leaves or macrophytodetritus and more ${ }^{13} \mathrm{C}$ enriched than the attached epiphytic biofilm. The analogous harpacticoid copepod signatures in all three seagrass material habitats suggest that they feed on similar sources, independent of the habitat where they occur. The SIAR mixing model revealed that epiphytes contribute more to the carbon resource for harpacticoid copepods than plant material, living or macrophytodetrital, do. This was congruent with the conclusion of Fry et al. (1987) on the basis that epiphytic algae can have an equal or greater nutritional importance than seagrasses for consumers in seagrass meadows. Since the outcome of the mixing model for SMF was biased due to the non-separation of the epiphytes from the leaves, no clear conclusion can be drawn for this particular habitat.

Harpacticoid copepods are known to feed on a variety of food sources (Hicks \& Coull, 1983) and they can colonize plastic seagrass mimics (De Troch et al., 2005). It was known that the epiphytic biofilm consists of different food sources ranging from cyanobacteria to diatoms and fungi and consequently represents a very variable food quality (Novak, 1984; Lepoint et al., 2006). The macrophytodetritus epiphytic biofilm compared to the seagrass epiphytic biofilm was composed of a higher number of detrital organisms, such as fungi and bacteria (Lepoint et al., 2006). Therefore we can hypothesize that the main reason why epiphytes contribute primarily to the food supply of harpacticoid copepods was due to the richer organic content in comparison to the poor macrophytodetrital material. Nevertheless, the isotopic composition did not exclude the occurrence of seagrass and macrophytodetritus in the diet of copepods. The question arose as to whether harpacticoid copepods actively graze on plant material or accidently ingest and assimilate it during epiphytic biofilm grazing. The isotopic signatures of $P$. oceanica macrophytodetritus (LMF and SMF) differ from living leaves (LL) by $3.9 \pm 1.1 \%$. This can be explained by the fractionation during decomposition. Nutrients are resorbed in senescing leaves before abscission and labile nutrients are quickly mobilized by bacterial degradation (Mateo \& Romero, 1997). Next to the decomposition fractionation, the origin of the macrophytodetrital leaves could play a major role. Macrophytodetritus found on the studied sand patch does not necessarily come from the adjacent meadow but may be from deeper meadows which exhibit a lower isotopic signature 
due to the light constraint on photosynthesis rate (Lepoint et al., 2003).

\section{CONCLUSIONS}

Meiofauna community assemblages were similar in the five habitats analysed in the present study. Meiofauna densities were the highest in the bare sand, followed by large macrophytodetritus fragments compared to the other core sampled habitats. Harpacticoid copepods were found to be the most abundant taxa and had the highest density in large macrophytodetritus fragments compared to the other seagrass material habitats. On the basis of harpacticoid copepod assemblage structure, the five different habitats were divided in two main clusters: a sediment group and a leaf habitat group. The small macrophytodetritus fragments showed a higher similarity with both sand habitats in harpacticoid copepod composition and therefore can thus be considered to be more similar to sediment habitats than to phytal habitats. Copepod stable isotope signatures were similar, which indicates they feed on analogous food sources in the different habitats. As epiphytes contribute for $70 \%$ to the copepods' carbon signature in living leaves and large macrophytodetritus fragments, they appear to be the preferential carbon source for harpacticoid copepods (SIAR mixing model).

\section{ACKNOWLEDGEMENTS}

The authors warmly thank the Stareso field station staff for their support during the sampling campaign. The authors thank anonymous referees for their constructive remarks that contributed to the improvement of the manuscript. This is the MARE paper number (293).

\section{FINANCIAL SUPPDRT}

The first author acknowledges a PhD FRIA grant (Fund for Research Training in industry and in agriculture) of the Belgian National Fund for Scientific Research (FRS-FNRS) This work was part of the Master's thesis of the first author, to obtain the degree in Marine and Lacustrine Sciences, Ghent University (2010). This study was conducted within the frame of FRS-FNRS research project FRFC 2.4511 .09 (University of Liège) with additional support provided by the Ghent University (BOF-GOA 01GZ0705 and 01GA1911W). G. Lepoint is a Research Associate of the FRS-FNRS. M. De Troch is a postdoctoral fellow financed by the Special Research Fund of the Ghent University (BOF-GOA 01GA1911W).

\section{REFERENCES}

Armonies W. (1988) Active emergence of meiofauna from intertidal sediment. Marine Ecology Progress Series 43, 151-159.

Bay D. (1984) A field study of the growth dynamics and productivity of Posidonia oceanica (L.) delile in Calvi Bay, Corsica. Aquatic Botany 20, 43-64.

Bell S.S. and Hicks G.R.F. (1991) Marine landscape and faunal recruitment-a field test with seagrasses and copepods. Marine Ecology Progress Series 73, 61-68.
Bell S.S., Kern J.C. and Walters C. (1984) Sampling for meiofaunal taxa in seagrass systems. In Thompson M.-F. (ed.) Biology of benthic marine organisms. New Delhi: Oxford IBH.

Bonsdorff E. (1992) Drifting algae and zoobenthos-effects on settling and community structure. Netherlands Journal of Sea Research 30, 57-62.

Boxshall G.A. and Hasley S.H. (2004) An introduction to copepods diversity. London: The Ray Society.

Caramujo M.J., Boschker H.T.S. and Admiraal W. (2008) Fatty acid profiles of algae mark the development and composition of harpacticoid copepods. Freshwater Biology 53, 77-90.

Cardona L., Revelles M., Sales M., Aguilar A. and Borrell A. (2007) Meadows of the seagrass Posidonia oceanica are a significant source of organic matter for adjoining ecosystems. Marine Ecology Progress Series $335,123-131$

Carlier A., Riera P., Amouroux J.-M., Bodiou J.-Y., Escoubeyrou K. Desmalades M., Caparros J. and Gremare A. (2007) A seasonal survey of the food web in the Lapalme Lagoon (northwestern Mediterranean) assessed by carbon and nitrogen stable isotope analysis. Estuarine, Coastal and Shelf Science 73, 299-315.

Cebrian J. and Duarte C.M. (2001) Detrital stocks and dynamics of the seagrass Posidonia oceanica (L.) Delile in the Spanish Mediterranean. Aquatic Botany 70, 295-309.

Clarke K.R. and Gorley R.N. (2006) PRIMER v6. User Manual/Tutorial. Plymouth: PRIMER-E.

Danovaro R. (1996) Detritus - bacteria-meiofauna interactions in a seagrass bed (Posidonia oceanica) of the NW Mediterranean. Marine Biology 127, 1-13.

Danovaro R., Gambi C., Manini E. and Fabiano M. (2000) Meiofauna response to a dynamic river plume front. Marine Biology 137, 359-370.

Danovaro R., Gambi C. and Mirto S. (2002) Meiofaunal production and energy transfer efficiency in a seagrass Posidonia oceanica bed in the western Mediterranean. Marine Ecology Progress Series 234, 95-104.

Dauby P. and Poulicek M. (1995) Methods for removing epiphytes from seagrasses: SEM observations on treated leaves. Aquatic Botany 52 , $217-228$.

De Troch M., Chepurnov V.A., Vincx M. and Olafsson E. (2008) The effect of Fucus vesiculosus on the grazing of harpacticoid copepods on diatom biofilms. Journal of Sea Research 6o, 139-143.

De Troch M., Cnudde C., Vyverman W. and Vanreusel A. (2009) Increased production of faecal pellets by the benthic harpacticoid Paramphiascella fulvofasciata: importance of the food source. Marine Biology 156, 469-477.

De Troch M., Gurdebeke S., Fiers F. and Vincx M. (2001) Zonation and structuring factors of meiofauna communities in a tropical seagrass bed (Gazi Bay, Kenya). Journal of Sea Research 45, 45-61.

De Troch M., Vandepitte L., Raes M., Suarez-Morales E. and Vincx M. (2005) A field colonization experiment with meiofauna and seagrass mimics: effect of time, distance and leaf surface area. Marine Biology 148, 73-86.

Dimech M., Borg J.A. and Schembri P.J. (2006) Motile macroinvertebrate assemblages associated with submerged Posidonia oceanica litter accumulations. Biologia Marina Mediterranea 13, 130-133.

Duarte C.M., Middelburg J.J. and Caraco N. (2005) Major role of marine vegetation on the oceanic carbon cycle. Biogeosciences 2, 1-8.

Fonseca G., Hutchings P. and Gallucci F. (2011) Meiobenthic communities of seagrass beds (Zostera capricorni) and unvegetated sediments along the coast of New South Wales, Australia. Estuarine, Coastal and Shelf Science 91, 69-77. 
Fry B., Macko S.A. and Zieman J.C. (1987) Review of stable isotopic investigation of food webs in seagrass meadows. Florida Marine Research Publications 42, 189-209.

Gallmetzer I., Pflugfelder B., Zekely J. and Ott J.A. (2005) Macrofauna diversity in Posidonia oceanica detritus: distribution and diversity of mobile macrofauna in shallow sublittoral accumulations of Posidonia oceanica detritus. Marine Biology 147, 517-523.

Giere O. (2009) Meiobenthology-the microscopic motile fauna of aquatic sediments. 2nd edition. Berlin: Springer.

Gobert S., Kyramarios M., Lepoint G., Pergent-Martini C. and Bouquegneau J.M. (2003) Variations at different spatial scales of Posidonia oceanica (L.) Delile beds; effects on the physico-chemical parameters of the sediment. Oceanologica Acta 26, 199-207.

Hall M.O. and Bell S.S. (1993) Meifauna on the seagrass Thalassia testudinum. Population characteristics of harpacticoid copepods ans associations with algal epiphytes. Marine Biology 116, 137-146.

Hemminga M.A. and Mateo M.A. (1996) Stable carbon isotopes in seagrasses: variability in ratios and use in ecological studies. Marine Ecology Progress Series 140, 285-298.

Hicks G.R. and Coull B.C. (1983) The ecology of marine meiobenthic harpacticoid copepods. Oceanography and Marine Biology: an Annual Review 21, 67-175.

Higgins R. and Thiel H. (1988) Introduction to the study of meiofauna. London: Smithsonian Institution Press.

Hooper G.J. and Davenport J. (2006) Epifaunal composition and fractal dimensions of intertidal marine macroalgae in relation to emersion. Journal of the Marine Biological Association of the United Kingdom 86, 1297-1304.

Hulings N.C. and Gray J.S. (1971) A manual for the study of meiofauna. Smithsonian Contributions to Zoology 78, 1-83.

Huys R. and Boxshall G.A. (1991) Copepod evolution. London: The Ray Society, $159 \mathrm{pp}$.

Lang K. (1948) Monographie der Harpacticiden. Lund: Hâkan Ohlssons boktryckeri.

Lang K. (1965) Copepoda Harpacticoidea from the Californian Pacific Coast. Stockholm: Almqvist \& Wiksell.

Lepoint G., Cox A.S., Dauby P., Poulicek M. and Gobert S. (2006) Food sources of two detritivore amphipods associated with the seagrass Posidonia oceanica leaf litter. Marine Biology Research 2, 355-365.

Lepoint G., Dauby P., Fontaine M., Bouquegneau J.M. and Gobert S. (2003) Carbon and nitrogen isotopic ratios of the seagrass Posidonia oceanica: depth-related variations. Botanica Marina 46, 555-561.

Lepoint G., Defawe O., Gobert S., Dauby P. and Bouquegneau J.M. (2002) Experimental evidence for $\mathrm{N}$ recycling in the leaves of the seagrass Posidonia oceanica. Journal of Sea Research 48, 173-179.

Lepoint G., Nyssen F., Gobert S., Dauby P. and Bouquegneau J.M. (2000) Relative impact of a seagrass bed and its adjacent epilithic algal community in consumer diets. Marine Biology 136, 513-518.

Losi V., Montefalcone M., Moreno M., Giovannetti E., Gaozza L., Grondona M. and Albertelli G. (2012) Nematodes as indicators of environmental quality in seagrass (Posidonia oceanica) meadows of the NW Mediterranean Sea. Advances in Oceanography and Limnology 3, 69-91.

Mateo M.A. and Romero J. (1997) Detritus dynamics in the seagrass Posidonia oceanica: elements for an ecosystem carbon and nutrient budget. Marine Ecology Progress Series 151, 43-53.

Mateo M.A., Sanchez-Lizaso J.L. and Romero J. (2003) Posidonia oceanica 'banquettes': a preliminary assessment of the relevance for meadow carbon and nutrients budget. Estuarine, Coastal and Shelf Science 56, 85-90.
Mirto S., Bianchelli S., Gambi C., Krzelj M., Pusceddu A., Scopa M., Holmer M. and Danovaro R. (2010) Fish-farm impact on metazoan meiofauna in the Mediterranean Sea: analysis of regional vs. habitat effects. Marine Environmental Research 69, 38-47.

Mirto S. and Danovaro R. (2004) Meiofaunal colonisation on artificial substrates: a tool for biomonitoring the environmental quality on coastal marine systems. Marine Pollution Bulletin 48, 919-926.

Nieuwenhuize J., Maas Y.E.M. and Middelburg J.J. (1994) Rapid analysis of organic-carbon and nitrogen in particulate materials. Marine Chemistry 45, 217-224.

Norkko J., Bonsdorff E. and Norkko A. (2000) Drifting algal mats as an alternative habitat for benthic invertebrates: species specific responses to a transient resource. Journal of Experimental Marine Biology and Ecology 248, 79-104.

Novak R. (1984) A study in ultra-ecology-microorganisms on the seagrass Posidonia oceanica. Marine Ecology-Pubblicazioni Della Stazione Zoologica Di Napoli I 5, 143-190.

Parnell A.C., Inger R., Bearhop S. and Jackson A.L. (2010) Source partitioning using stable isotopes: coping with too much variation. Plos One 5(3). Available at: http://www.plosone.org/article/info:doi/10. 1371/journal.pone.0009672.

Peachey R.L. and Bell S.S. (1997) The effects of mucous tubes on the distribution, behavior and recruitment of seagrass meiofauna. Journal of Experimental Marine Biology and Ecology 209, 279-291.

Pergent-Martini C., Rico-Raimondino V. and Pergent G. (1994) Primary production of Posidonia oceanica in the Mediterranean Basin. Marine Biology 120, 9-15.

Pergent G., Rico-Raimondino V. and Pergent-Martini C. (1997) Fate of primary production in Posidonia oceanica meadows of the Mediterranean. Aquatic Botany 59, 307-321.

Romero J., Pergent G., Pergentmartini C., Mateo M.A. and Regnier C. (1992) The detritic compartement in a Posidonia oceanica meadowlitter features, decomposition rates and mineral stocks. Marine Ecology-Pubblicazioni Della Stazione Zoologica Di Napoli I 13, 69-83.

Sturaro N., Caut S., Gobert S., Bouquegneau J.-M. and Lepoint G. (2010) Trophic diversity of idoteids (Crustacea, Isopoda) inhabiting the Posidonia oceanica litter. Marine Biology 157, 237-247.

Thistle D. and Sedlacek L. (2004) Emergent and non-emergent species of harpacticoid copepods can be recognized morphologically. Marine Ecology Progress Series 266, 195-200.

Vander Zanden M.J. and Rasmussen J.B. (2001) Variation in delta N-15 and delta $\mathrm{C}-13$ trophic fractionation: Implications for aquatic food web studies. Limnology and Oceanography 46, 2061-2066.

Vizzini S., Sara G., Michener R.H. and Mazzola A. (2002) The role and contribution of the seagrass Posidonia oceanica (L.) Delile organic matter for secondary consumers as revealed by carbon and nitrogen stable isotope analysis. Acta Oecologica-International Journal of Ecology 23, 277-285.

Webb D.G. (1990) Intrashoot distributions of leaf dwelling harpacticoid copepods on the seagrass Zostera marina-implications for sampling design. Hydrobiologia 206, 155-162.

and

Wyckmans M., Chepurnov V.A., Vanreusel A. and De Troch M. (2007) Effects of food diversity on diatom selection by harpacticoid copepods. Journal of Experimental Marine Biology and Ecology 345, 119-128.

\section{Correspondence should be addressed to:}

T. Mascart

Marine Biology, Ghent University

Krijgslaan 281-S8, B-900o Ghent, Belgium

email: thibaud.mascart@ugent.be 